\title{
ACCESSIBILITY AS A FRAMEWORK FOR SUSTAINABLE TRANSPORTATION PLANNING IN THE TIJUANA-ROSARITO- TECATE METROPOLITAN REGION
}

\author{
E. PAEZ FRIAS \& F. CUAMEA VELAZQUEZ \\ Autonomous University of Baja California, Mexico.
}

\begin{abstract}
One of the basic goals of urban sustainability is to manage urban flows efficiently. Urban transportation is considered one of the aspects that largely generate environmental, social and economic impacts in cities and urban regions. With the increase of automobile dependence, the new perspective about urban transportation has to favor accessibility over mobility. Accessibility is considered one of the main goals of sustainable transportation and it is used as a good concept to develop an integrated land use-transportation planning process. According to this, this paper examines the relationship between urban form and transportation in the TijuanaRosarito-Tecate metropolitan region, located in the cross border space between Mexico and the Unites States of America, as a framework to implement a more integrated planning process. The research is conducted at three scales: urban, metropolitan and cross border space. The first stage of this study is developed at the urban scale (Tijuana), analyzing data at the city and district level. Linear correlation analysis was implemented to identify the relation of land use factors and automobile trips. The results in this first stage indicate at the city level that population density and distance from center have negative correlations with automobile trips; significance correlation between urban form factors evidence a segregated land use pattern in Tijuana. At the district level, negative correlations appear in other factors (job density, land use mixture and transit routes density) with no relevant significance; nevertheless, core districts appear as the ones which urban conditions favor other transportation modes. Preliminary conclusions indicate that urban conditions of core districts could be implemented in the rest of the city through new zoning and transportation strategies.
\end{abstract}

Keywords: accessibility, land use-transportation interaction, metropolitan region, sustainable transportation.

\section{INTRODUCTION}

Numerous studies emphasize the relation between urban form and transportation as a fundamental indicator of urban sustainability. Travel demand around the city, the access to all transportation modes, and the proximity of destinations, determine the need of energy to support urban flows. The efficiency of land use and transportation systems determine the population capacity to reach desired destinations, enhance economic activities and reduce the environmental impacts that motorized trips could generate. By consequence, sustainable transportation seeks to minimize the consumption of energy and to reduce contaminants; at the same time, it maximizes the efficiency of urban form. Thus, the sustainable condition of mobility refers to the concept of accessibility, which can be used as a good framework to design integral land use and transportation policies, since it involves characteristics of both planning systems [1].

In the Tijuana-Rosarito-Tecate metropolitan region - a cross border space between Mexico and the United States of America - achieving accessibility will depend on the adequate distribution of urban activities, the efficiency of the metropolitan spatial structure and the effective operation of international ports of entry. In this way, the analysis by scales will allow to identify needs to sustainable transportation management in each scale of coordination.

This paper examines the relationship between urban form and transportation through the concept of accessibility in the Tijuana-Rosarito-Tecate metropolitan region, as a framework to implement a more integrated planning process. The application of the methodology at the urban scale in Tijuana is presented as a first phase of the research. 


\section{URBAN TRANSPORTATION AND ACCESSIBILITY}

\subsection{Sustainable transportation}

Traditionally, city transportation has been a traffic engineering issue which address the automobile (and other motorized vehicles) demand to move faster and efficiently around the city [2-4]. Sustainability incorporated new considerations to urban transportation; now, urban transportation should not only give functionality to motor vehicles (mobility) but also they should incorporate accessibility as a condition for sustainable transportation.

For the DG Research team [5], urban transportation is one of the crucial elements of sustainability; sustainable transportation implies the simultaneous request to reduce environmental impacts and to increase accessibility for all the inhabitants, for that matter, it is recommended that transportation planning should be integrated into spatial planning, over a general base of sustainable development management.

\subsection{The land use-transportation interaction and the concept of accessibility}

Urban growth and automobile dependence generate important impacts that should be recognized at the economic, social and environmental fields [6]. To deal with these impacts, it is important to understand land use and transportation interaction. Wegener and Fürst [7] recognized that travel patterns and activities location influence one another creating a cyclic scheme that feeds back the land use-transportation interaction.

There are a series of coincidences in the interpretation of the spatial structure (land uses) that largely have impact on travel behavior. Stead and Marshall [8] analyzed urban form aspects that influence travel behavior through different geographic scales. They noticed that the significance of each aspect depends on the context, the quality of evidence, the scale of the analysis and the causality of relations; at the end, urban planning is the suitable process to coordinate and manage the diversity of land use and transportation elements.

For Silva and Pinho [1], the concept of accessibility can be used as a good background to design integrated land use and transportation policies, since this concept considers characteristics of both planning processes. While many more researches affirm that transportation planning must be part of the land use planning process, accessibility is considered a key element in the analysis of transportation systems efficiency, an important characteristic of urban areas and a crucial link between transportation and land use planning [9].

De Sousa [10] affirms that accessibility has a significant role at the regional and local level (see Table 1). They identified that density of development, mixture of land uses and neighborhood type are the aspects most related with accessibility at different scales.

Procedures to analyze these factors have been used in a range of empirical exercises. The important of this evidence will serve to identify tasks towards land use-transportation planning processes.

\subsection{Methodological coincidences}

Although urban form-transportation interaction is a bi-directional process, most of the empiric research is based on analyzing the impacts of urban form over travel behavior [7].

Literature analysis allowed concluding that the interpretation of urban form and transportation factors differ according to local conditions, information availability and research goals (see Table 2). 
Table 1: Urban form and accessibility interactions [10].

\begin{tabular}{|c|c|c|c|c|}
\hline \multirow[b]{3}{*}{ Urban form aspect } & \multicolumn{4}{|c|}{ Relation with place accessibility } \\
\hline & \multicolumn{2}{|c|}{ Spatial scale } & \multicolumn{2}{|c|}{ Transport mode } \\
\hline & Regional & Local & Car & Non-car \\
\hline Density of development & $\bullet$ & $\bullet$ & $\bullet$ & $\bullet \bullet$ \\
\hline Mixing of land uses & $\bullet$ & $\bullet$ & $\bullet$ & $\bullet$ \\
\hline Neighborhood type & $\bullet$ & $\bullet$ & $\bullet$ & $\bullet$ \\
\hline Distance of residence to urban center & $\bullet$ & & $\circ$ & $\circ$ \\
\hline Settlement size & $\bullet$ & & $\circ$ & $\bullet$ \\
\hline Proximity to transport networks & $\bullet$ & $\circ$ & & $\bullet$ \\
\hline Road network type & $\circ$ & $\circ$ & $\bullet$ & $\bullet \bullet$ \\
\hline Provision of local facilities & & $\bullet$ & $\circ$ & $\bullet$ \\
\hline Availability of residential parking & & $\circ$ & $\bullet$ & \\
\hline
\end{tabular}

••: Strong relationship.

$\circ$ : Weak relationship.

In general (considering the need to reduce the number, distance and time of automobile trips through urban form management) urban aspects are used as independent variables while transportation factors act as dependent variables. Most of the analysis procedures are based in statistical correlations, case studies or comparative cases. Empirical evidence found that urban form factors are related with travel behavior. Automobile trips seem to be reducing in higher density zones and land use mixed areas. In the Tijuana-Rosarito-Tecate metropolitan region, the concepts of density and diversity (by geographical scales) will be used to evaluate accessibility and urban form efficiency.

\section{URBAN FORM AND TRANSPORTATION INTERACTION IN THE TIJUANA- ROSARITO-TECATE METROPOLITAN REGION}

Located to the northwest of Baja California, Mexico (see Fig. 1), the Tijuana-Rosarito-Tecate metropolitan region had 1.5 million inhabitants in 2005, with an annual growth rate of $2.7 \%$ [16]. By 2005, this metropolitan region covers 28,000 hectares of urbanized land in which Tijuana represents the core city. With about 1.3 million inhabitants, Tijuana supports an urban mobility of 2 million trips per day, because of a high car ownership (one vehicle for every 3.4 inhabitants). The international vicinity with San Diego, California, establish an important cross border mobility patterns through three ports of entry, supporting 54 million vehicular crossings yearly [17].

The San Diego Association of Governments (Sandag) considers Tijuana-San Diego as the biggest cross border urbanized area along the US-Mexican border, since it contains $34 \%$ of total population, with a cross border movement of 90,000 vehicles daily through its international ports of entry [18]. Some of the most important aspects that have driven the relations between governments and planning staffs between both sides of the border have been cross border transportation planning and environmental issues [19].

According to the Tijuana-Rosarito 2000-2005 Air Quality Program, 'Tijuana-Rosarito-San Diego region shares the same atmospheric basin that generates binational implications ...' [20]. 
Table 2: Methodological aspects identified in the literature review.

\begin{tabular}{|c|c|c|c|c|}
\hline \multirow[b]{2}{*}{ Hypothesis } & \multicolumn{2}{|c|}{ Variables $^{\mathrm{a}}$} & \multirow[b]{2}{*}{ Analysis procedures } & \multirow[b]{2}{*}{ Authors } \\
\hline & $\begin{array}{l}\text { Urban form } \\
\text { (independent) }\end{array}$ & $\begin{array}{c}\text { Transportation } \\
\text { (dependent) }\end{array}$ & & \\
\hline $\begin{array}{l}\text { Density is the } \\
\text { factor that more } \\
\text { influences travel } \\
\text { behavior. Higher } \\
\text { density - less } \\
\text { automobile trips }\end{array}$ & $\begin{array}{l}\text { Residential } \\
\text { density } \\
\text { Job density }\end{array}$ & $\begin{array}{l}\text { Number of } \\
\text { automobile } \\
\text { trips } \\
\text { Length of } \\
\text { automobile } \\
\text { trips }\end{array}$ & $\begin{array}{l}\text { Simple correlations. } \\
\text { In order to identify } \\
\text { the weight of the } \\
\text { relation between } \\
\text { the variables of } \\
\text { urban form and }\end{array}$ & $\begin{array}{l}\text { Newman and } \\
\text { Kenworthy [11] } \\
\text { Milakis, Vlastos and } \\
\text { Barbopoulos [12] } \\
\text { Stead and Marshall [8] } \\
\text { Acker and }\end{array}$ \\
\hline $\begin{array}{l}\text { Diversity } \\
\text { (residential } \\
\text { concentration, } \\
\text { jobs and local } \\
\text { facilities) } \\
\text { generates } \\
\text { proximity and } \\
\text { reduce } \\
\text { automobile trips }\end{array}$ & $\begin{array}{l}\text { Housing-jobs } \\
\text { balance } \\
\text { Land use } \\
\text { mixture } \\
\text { (entropy } \\
\text { index) } \\
\text { Availability of } \\
\text { local facilities }\end{array}$ & $\begin{array}{l}\text { Proportion } \\
\text { public } \\
\text { transportation } \\
\text { trips } \\
\text { Energy } \\
\text { consumption } \\
\text { Emissions }\end{array}$ & $\begin{array}{l}\text { transportation } \\
\text { Multiple correlations. } \\
\text { To manage } \\
\text { socioeconomic } \\
\text { variables } \\
\text { Case study. Analysis } \\
\text { according to the } \\
\text { selection of city } \\
\text { districts with similar }\end{array}$ & $\begin{array}{l}\text { Witlox Go [13] } \\
\text { Bertaud [14] } \\
\text { Wegener and } \\
\text { Fürst [7] } \\
\text { Litman [4] } \\
\text { Lawrence D. Frank } \\
\text { and Pivo [15] } \\
\text { Silva and Pinho [1] }\end{array}$ \\
\hline $\begin{array}{l}\text { Neighborhood } \\
\text { design } \\
\text { contributes in } \\
\text { some cases } \\
\text { to decrease } \\
\text { journeys in car } \\
\text { and promote an } \\
\text { increase trips on } \\
\text { foot }\end{array}$ & $\begin{array}{l}\text { Urban design } \\
\text { and design } \\
\text { of streets } \\
\text { Distance } \\
\text { to transit } \\
\text { routes or } \\
\text { transporting } \\
\text { stations } \\
\text { Distance } \\
\text { to roads, } \\
\text { proportion } \\
\text { of road } \\
\text { surface per } \\
\text { capita }\end{array}$ & & $\begin{array}{l}\text { characteristics } \\
\text { that respond to the } \\
\text { research suppositions } \\
\text { Comparative cases. } \\
\text { Comparative of } \\
\text { urban form and } \\
\text { transportation } \\
\text { correlation indexes } \\
\text { related with different } \\
\text { city districts to } \\
\text { explain based in } \\
\text { urban characteristics } \\
\text { observed }\end{array}$ & \\
\hline $\begin{array}{l}\text { More compact } \\
\text { and accessible } \\
\text { land uses help to } \\
\text { attain sustainable } \\
\text { transportation } \\
\text { goals }\end{array}$ & $\begin{array}{l}\text { Distance to } \\
\text { centers } \\
\text { Centrality }\end{array}$ & & & \\
\hline
\end{tabular}

${ }^{\mathrm{a} C}$ Control variables: car ownership, license possession, household size, age, gender, education and socioeconomic level. 


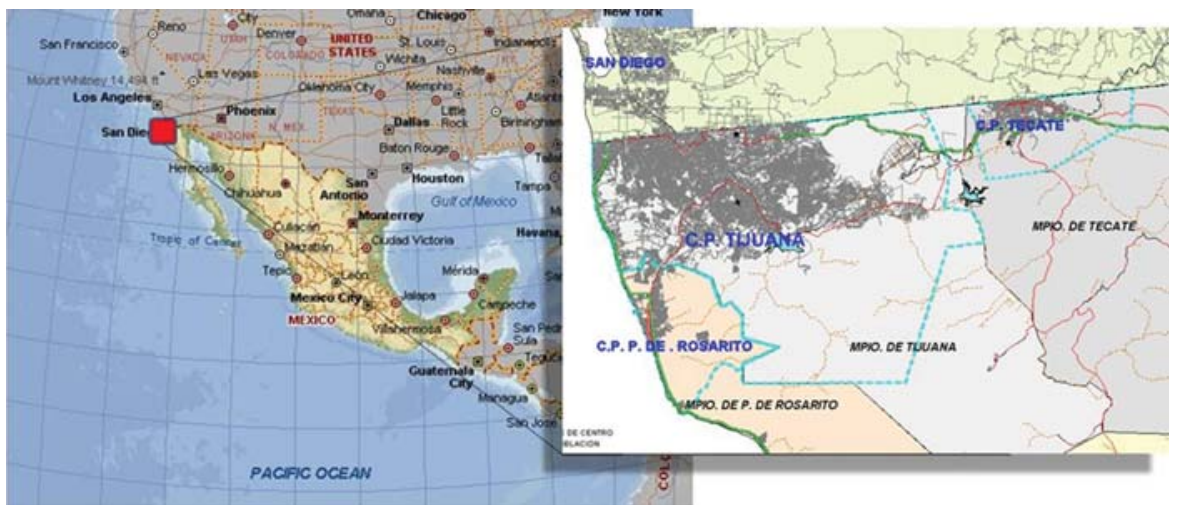

Figure 1: The Tijuana-Rosarito-Tecate metropolitan region.

The 2009-2030 Tijuana Urban Development Program points out than in addition to the increment of automobiles, other aspects that affect air quality are: 'lack of mobility and the uneven urban development that is generated by growing areas located far from services, which increase distances and trips' [17]. According to the 1998 Emissions Inventory, transportation is the most important factor that impacts air quality in Tijuana and Playas de Rosarito, since it contributes to $74 \%$ of air contaminants [17].

Since the 1980s, land use planning has been practiced in the Tijuana-Rosarito-Tecate metropoli$\tan$ region. However, there was not any planning exercise which had linked land use and transportation analysis; each system is studied separately and so the policies that had been applied.

\subsection{Methodology}

This exercise links some urban form and transportation factors in the Tijuana-Rosarito-Tecate metropolitan region, considering variables to evaluate land use-transportation interaction at urban, metropolitan and cross border scale. Concepts and variables are shown in Table 3. Hypothesis formulation is based on the assumption that urban and regional accessibility can be achieved through urban form management to reduce automobile trips (see Table 3). Figure 2 explains graphically the fundamentals of the analysis at each scale.

The first phase of this research includes the analysis at urban scale (city of Tijuana). This process was structured at city and district levels; a GIS was developed using Mapinfo as the software platform. Information for each variable will be assigned to each census track, then grouped at district scale (see Fig. 3). Basic statistics are presented to analyze dispersion of data for each indicator. Also, Moran's coefficient (I) was applied using the Arc View platform to analyze clustering of information considering spatial autocorrelation (Moran's autocorrelation coefficient evaluates if the pattern expressed of the data is clustered, disperse or random. Value of -1 expresses disperse data, 0 expresses random values and 1 expresses clustering.). To evaluate urban form-transportation interactions, statistical analysis with SPSS was implemented at city and district levels. Scatter charts and Pearson correlation coefficients determined the direction of the interaction and its significance. The graphic representation of Pearson coefficients will allow comparing land use-transportation interaction among districts. Other transportation modes (walking and transit) will be correlated with urban form factors to confirm conclusions related with core districts. 
Table 3: Hypothesis and variables at each scale of analysis.

\begin{tabular}{|c|c|c|c|c|}
\hline \multirow[b]{2}{*}{ Scale } & \multirow[b]{2}{*}{ Hypothesis } & \multicolumn{2}{|c|}{ Variable } & \multirow[b]{2}{*}{$\begin{array}{l}\text { Sources of } \\
\text { information }\end{array}$} \\
\hline & & $\begin{array}{l}\text { Dependent } \\
\text { (transportation) }\end{array}$ & $\begin{array}{l}\text { Independent } \\
\text { (urban form) }\end{array}$ & \\
\hline \multirow[t]{4}{*}{ Urban } & $\begin{array}{l}\text { Higher densities } \\
\text { (population and jobs) } \\
\text { generate fewer } \\
\text { automobile trips }\end{array}$ & $\begin{array}{l}\text { Automobile trips } \\
\text { proportion }\end{array}$ & $\begin{array}{l}\text { Population } \\
\text { density } \\
\text { Job density }\end{array}$ & $\begin{array}{l}\text { O/D survey for } \\
\text { Tijuana [21] } \\
\text { Demographic } \\
\text { census [22] } \\
\text { Economic } \\
\text { census [23] }\end{array}$ \\
\hline & $\begin{array}{l}\text { Higher land use mixture } \\
\text { generates fewer } \\
\text { automobile trips }\end{array}$ & $\begin{array}{l}\text { Automobile trips } \\
\text { proportion }\end{array}$ & $\begin{array}{l}\text { Proportion of } \\
\text { land uses not } \\
\text { residential }\end{array}$ & $\begin{array}{l}\text { O/D survey for } \\
\text { Tijuana [21] } \\
\text { Land use survey } \\
\text { [17] }\end{array}$ \\
\hline & $\begin{array}{l}\text { Higher transit routes } \\
\text { density generates fewer } \\
\text { automobile trips }\end{array}$ & $\begin{array}{l}\text { Automobile trips } \\
\text { proportion }\end{array}$ & $\begin{array}{l}\text { Transit routes } \\
\text { density }\end{array}$ & $\begin{array}{l}\text { O/D survey for } \\
\text { Tijuana [21] } \\
\text { Transit routes [17] }\end{array}$ \\
\hline & $\begin{array}{l}\text { The longer the distance } \\
\text { from CBD more } \\
\text { automobile trips }\end{array}$ & $\begin{array}{l}\text { Automobile trips } \\
\text { proportion }\end{array}$ & $\begin{array}{l}\text { Distance from } \\
\text { center }\end{array}$ & $\begin{array}{l}\text { O/D survey for } \\
\text { Tijuana [21] }\end{array}$ \\
\hline Metropolitan & $\begin{array}{l}\text { Effective policentricity in } \\
\text { the Tijuana-Rosarito- } \\
\text { Tecate region depends } \\
\text { on density } \\
\text { concentration } \\
\text { (population and job) } \\
\text { around each urban center }\end{array}$ & $\begin{array}{l}\text { Automobile trips } \\
\text { proportion } \\
\text { Average travel } \\
\text { time }\end{array}$ & $\begin{array}{l}\text { Population and } \\
\text { job densities } \\
\text { from local } \\
\text { centers }\end{array}$ & $\begin{array}{l}\text { O/D survey for } \\
\text { Tijuana [21] } \\
\text { Demographic } \\
\text { census [22] } \\
\text { Economic } \\
\text { census [23] }\end{array}$ \\
\hline Cross border & $\begin{array}{l}\text { There is a direct relation } \\
\text { between automobile } \\
\text { waiting time reduction } \\
\text { on international ports of } \\
\text { entry and the reduction } \\
\text { of fuel consumption and } \\
\mathrm{CO}_{2} \text { production }\end{array}$ & $\begin{array}{l}\text { Fuel consumption } \\
\mathrm{CO}_{2} \text { emissions }\end{array}$ & $\begin{array}{l}\text { Waiting times in } \\
\text { international } \\
\text { ports of entry }\end{array}$ & $\begin{array}{l}\text { SANDAG (San } \\
\text { Diego } \\
\text { Association of } \\
\text { Governments) } \\
\text { GSA (General } \\
\text { Service } \\
\text { Administration) }\end{array}$ \\
\hline
\end{tabular}

\subsection{Results at urban scale}

\subsubsection{Analysis at the city level}

Table 4 shows basic statistics for each indicator. The Moran's autocorrelation coefficients demonstrate data tendencies to clustering. Figure 4 presents the graphic representation of indicators for the city of Tijuana. Clustering of indicators could be seen in job density, transit routes density and non-residential uses, while other factors present a more disperse space distribution. 


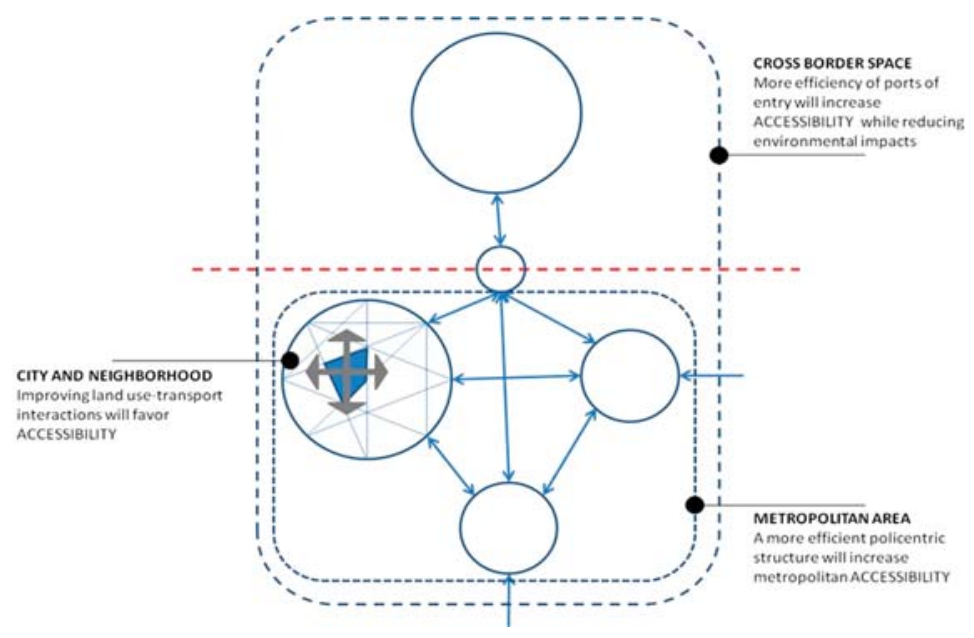

Figure 2: Accessibility conceptualization in the Tijuana-Rosarito-Tecate metropolitan region.

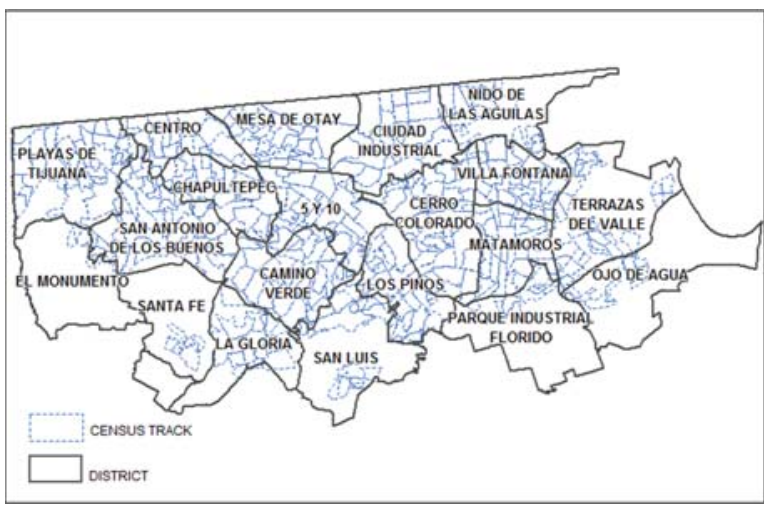

Figure 3: Geographic units in Tijuana.

Table 4: Basic statistics of indicators and Moran's coefficients.

\begin{tabular}{lcccccc}
\hline Indicator & $\mathrm{N}$ & Minimum & Maximum & Mean & Standard deviation & Moran's I \\
\hline Population density & 396 & 0.00 & 383.70 & 77.5753 & 53.4957 & 0.40 \\
Jobs density & 396 & 0.00 & 175.69 & 10.8896 & 20.2402 & 0.30 \\
Non-residential uses & 396 & 0.00 & 99.374 & 12.7893 & 15.6291 & 0.31 \\
proportion & & & & & & \\
Transit routes density & 396 & 0.00 & 31.30 & 3.2318 & 4.0746 & 0.45 \\
Distance from center & 396 & 0.00 & 21.29 & 8.6330 & 4.9154 & 0.98 \\
Auto trips proportion & 396 & 0.00 & 100.00 & 28.6519 & 16.6786 & 0.36 \\
\hline
\end{tabular}



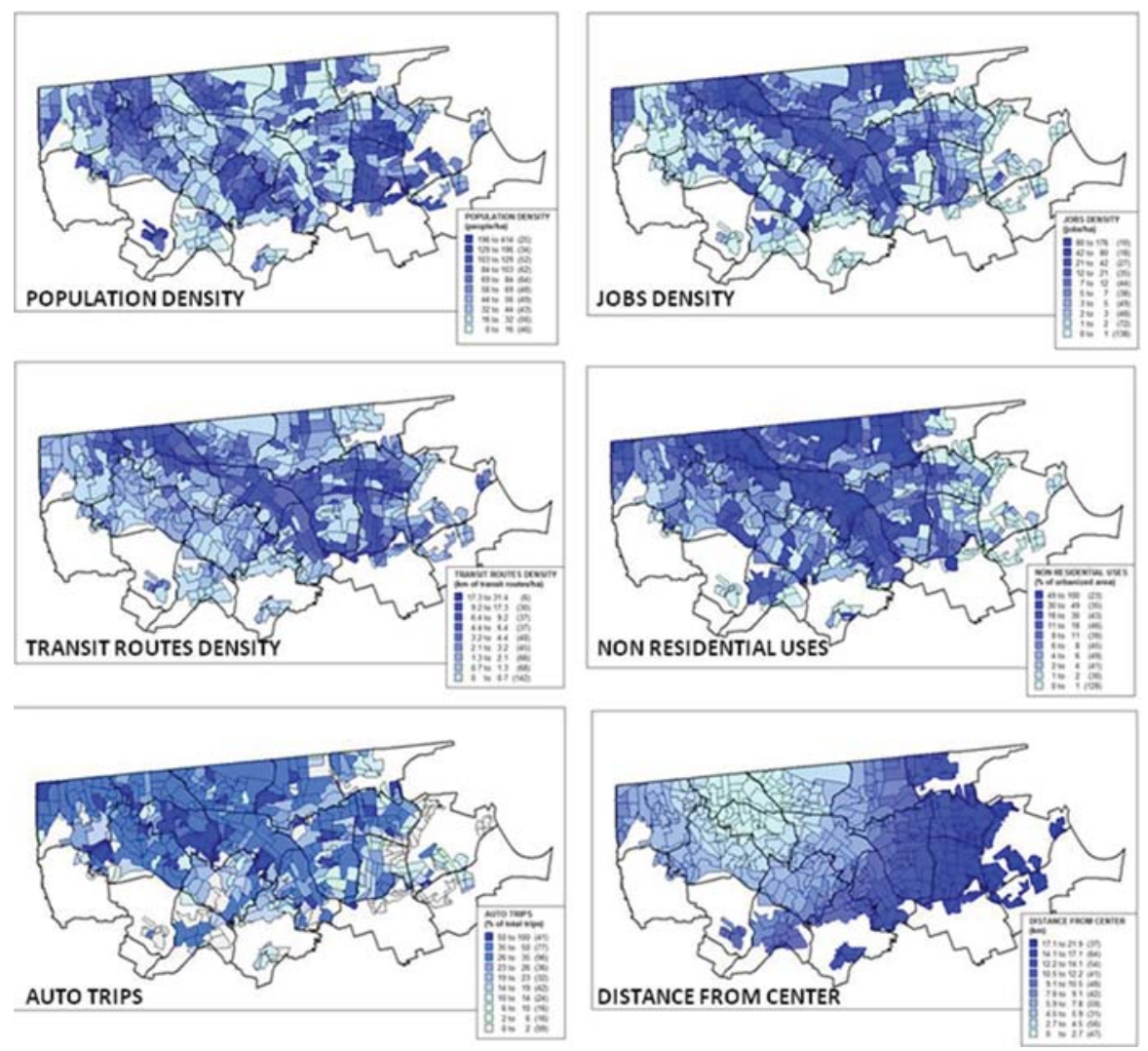

Figure 4: Graphic representation of indicators in the city of Tijuana.

Scatter charts (see Fig. 5) show that population density $\left(r^{2}=0.6947\right)$ and distance from center $\left(r^{2}=0.8033\right)$ are negatively correlated with auto trips, while the rest of urban form factors notice a positive correlation. Pearson correlation coefficients confirm that only population density and distance from center have a negative correlation with auto trips (see Table 5); nevertheless, considering statistical significance, only distance from center is negative correlated with auto trips within the city of Tijuana. That is a contradiction of generalized assumptions for cities in developed countries because there, the longer the distance from CBD the higher proportion of automobile trips, due to the suburbanization pattern of growth. Other contradictions arise in the correlations of non-residential uses and transit routes; there, the assumptions tell that mixed uses and concentration of transit routes reduce auto trips, which is the opposite in Tijuana.

Other important conclusions are related with the efficiency of Tijuana's spatial structure. Considering that some conditions of sustainable transportation refer to the conformation of spaces that include residence, employment and mixture of uses, in Tijuana the correlation among the variables of population density, job density and mixture of land uses were negative (most of them significantly correlated at the 0.01 level), which indicates a segregation of jobs and services within the city and that most of the housing areas function only as dormitories; also, a significant and positive correlation between the population density and the transit routes density can be seen as an efficient response of the transit system. 


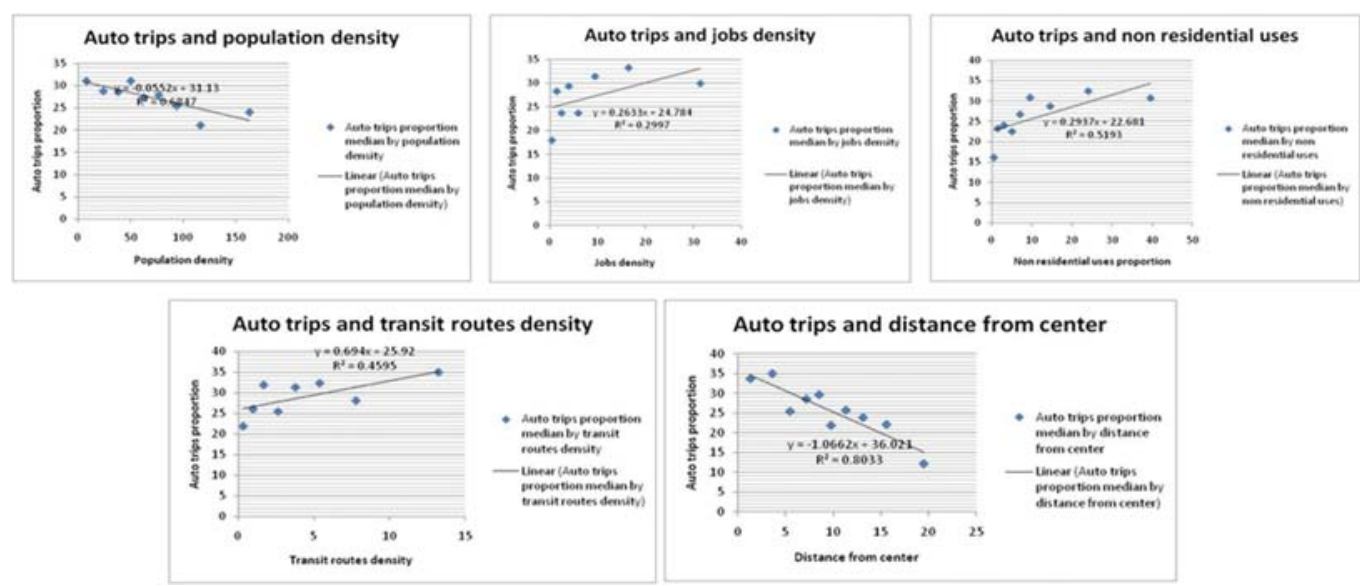

Figure 5: Correlation of urban form factors and auto trips in the city of Tijuana. The information at census track was organized by ranges; auto trips proportion correspond to the median of ranges.

Table 5: Pearson correlation of indicators at the city level.

\begin{tabular}{|c|c|c|c|c|c|c|c|}
\hline \multicolumn{8}{|c|}{ Correlation } \\
\hline & & $\begin{array}{c}\text { Population } \\
\text { density }\end{array}$ & Job density & $\begin{array}{l}\text { Non- } \\
\text { residential } \\
\text { uses }\end{array}$ & $\begin{array}{l}\text { Transit } \\
\text { routes } \\
\text { density }\end{array}$ & $\begin{array}{l}\text { Distance } \\
\text { from center }\end{array}$ & $\begin{array}{l}\text { Auto trips } \\
\text { proportion }\end{array}$ \\
\hline \multirow[t]{3}{*}{$\begin{array}{l}\text { Population } \\
\text { density }\end{array}$} & $\begin{array}{l}\text { Pearson } \\
\text { correlation }\end{array}$ & 1 & $-0.112^{*}$ & $-0.249 * *$ & $0.203 * *$ & $0.184 * *$ & -0.024 \\
\hline & $\begin{array}{l}\text { Sig. } \\
\text { (2-tailed) }\end{array}$ & & 0.026 & 0.000 & 0.000 & 0.000 & 0.628 \\
\hline & $\mathrm{N}$ & 396 & 396 & 396 & 396 & 396 & 396 \\
\hline \multirow[t]{3}{*}{$\begin{array}{l}\text { Jobs } \\
\text { density }\end{array}$} & $\begin{array}{l}\text { Pearson } \\
\text { correlation }\end{array}$ & -0.112 & 1 & $0.562 * *$ & $0.449 * *$ & $-0.166^{* *}$ & 0.72 \\
\hline & $\begin{array}{l}\text { Sig. } \\
\text { (2-tailed) }\end{array}$ & 0.026 & & 0.000 & 0.000 & 0.001 & 0.155 \\
\hline & $\mathrm{N}$ & 396 & 396 & 396 & 396 & 396 & 396 \\
\hline \multirow[t]{3}{*}{$\begin{array}{l}\text { Auto trips } \\
\text { proportion }\end{array}$} & $\begin{array}{l}\text { Pearson } \\
\text { correlation }\end{array}$ & -0.024 & 0.072 & $0.131 * *$ & $0.141^{* *}$ & $-0.316^{* *}$ & 1 \\
\hline & $\begin{array}{l}\text { Sig. } \\
\text { (2-tailed) }\end{array}$ & 0.628 & 0.155 & 0.009 & 0.005 & 0.000 & \\
\hline & $\mathrm{N}$ & 396 & 396 & 396 & 396 & 396 & 396 \\
\hline \multirow{3}{*}{$\begin{array}{l}\text { Non- } \\
\text { residential } \\
\text { uses }\end{array}$} & $\begin{array}{l}\text { Pearson } \\
\text { correlation }\end{array}$ & $-0.249 * *$ & $0.562 * *$ & 1 & $0.242 * *$ & $-0.303^{* *}$ & $0.131 * *$ \\
\hline & $\begin{array}{l}\text { Sig. } \\
\text { (2-tailed) }\end{array}$ & 0.000 & 0.000 & & 0.000 & 0.000 & 0.009 \\
\hline & $\mathrm{N}$ & 396 & 396 & 396 & 396 & 396 & 396 \\
\hline
\end{tabular}


Table 5: Continued

\begin{tabular}{|c|c|c|c|c|c|c|c|}
\hline \multirow{3}{*}{$\begin{array}{l}\text { Transit } \\
\text { routes } \\
\text { density }\end{array}$} & $\begin{array}{l}\text { Pearson } \\
\text { correlation }\end{array}$ & $0.203 * *$ & $0.449 * *$ & $0.242 * *$ & 1 & 0.097 & $0.141 * *$ \\
\hline & $\begin{array}{l}\text { Sig. } \\
\text { (2-tailed) }\end{array}$ & 0.000 & 0.000 & 0.000 & & 0.053 & 0.005 \\
\hline & $\mathrm{N}$ & 396 & 396 & 396 & 396 & 396 & 396 \\
\hline \multirow{3}{*}{$\begin{array}{l}\text { Distance } \\
\text { from } \\
\text { center }\end{array}$} & $\begin{array}{l}\text { Pearson } \\
\text { correlation }\end{array}$ & $0.184 * *$ & $-0.166 * *$ & $-0.303 * *$ & 0.097 & 1 & -0.316 \\
\hline & $\begin{array}{l}\text { Sig. } \\
\text { (2-tailed) }\end{array}$ & 0.000 & 0.001 & 0.000 & 0.053 & 396 & 0.000 \\
\hline & $\mathrm{N}$ & 396 & 396 & 396 & 396 & & 396 \\
\hline
\end{tabular}

* Correlation is significant at the 0.05 level (2-tailed).

$* *$ Correlation is significant at the 0.01 level (2-tailed).

\subsubsection{Analysis at the district level}

The analysis at the district level tried to identify those districts in which urban conditions were favorable to reduce automobile trips. The correlation analyzes for each series of data at the urban district are synthesized in Table 6 and shown in Fig. 6. The first row in Table 6 shows the Pearson correlation coefficients at the city level. In spite of the fact that most of the correlations at the city level are positive, it is possible to see that negative coefficients appear at the district level, most of them between population density and jobs density correlations. Nevertheless, almost no one of these correlations turn to be significant, so it is not possible to conclude a particular explanation from these results. Still, most of the negative coefficients refer to the correlation of population density and vehicular trips (10 out of 17 districts); also, correlations between jobs density, nonresidential uses and transit routes density with auto trips, contrary to what happened at the city level, showed negative coefficients in several districts. Again, no significant correlation appears.

Despite these results, two districts which correspond with the central space of the city of Tijuana presented 3 and 4 negative correlations: ' 5 and 10' and 'Centro'. Considering these two districts, Tables 7 and 8 show correlations between urban form factors and other transportation modes.

Urban form correlations for these two districts confirmed the segregated pattern of land uses that characterized the city of Tijuana; both districts presented positive significance correlation between jobs density and non-residential uses, at the same time, 'El Centro' had negative correlations between population density and jobs density and, population density and non-residential uses, while transit routes density correlates positively with non-residential uses (see Table 6). Considering other transportation modes, several important conclusions arise (see Table 7): in district ' 5 and 10' jobs density, non-residential uses and routes density are related with transit trips; on the other hand, 'El Centro' demonstrates that population density is related with walking trips and mix uses, and routes density is related with transit trips. This core districts are characterized by their concentration of housing, jobs, services and transit routes; the CBD, other commercial sub centers (Zona del Rio and 5 and 10) and the most important urban corridor are in this two districts; here, the proportion of residential use represent $50 \%$, while commercial, services and industry the other $50 \%$ of urbanized land. Also, urban pattern in this districts show an orthogonal street arrangement, some well design pedestrian paths and a fine urban landscape (see Fig. 7). These urban conditions could establish a framework to develop similar zoning strategies and transportation policies to apply in other districts. 
Table 6: Statistical analysis at the district level.

\begin{tabular}{|c|c|c|c|c|c|c|}
\hline \multirow[b]{2}{*}{ City/distric } & & \multirow[b]{2}{*}{$\mathrm{N}$} & \multicolumn{4}{|c|}{ Urban form/auto trips correlation } \\
\hline & & & $\begin{array}{c}\text { Population density/ } \\
\text { auto trips }\end{array}$ & $\begin{array}{l}\text { Jobs density/ } \\
\text { auto trips }\end{array}$ & $\begin{array}{c}\text { Non-residential } \\
\text { uses/auto trips }\end{array}$ & $\begin{array}{c}\text { Transit routes } \\
\text { density/auto trips }\end{array}$ \\
\hline \multirow[t]{2}{*}{ City } & & 396 & -0.024 & 0.072 & $0.131 * *$ & $0.141^{* *}$ \\
\hline & & & 0.628 & 0.155 & 0.131 & 0.005 \\
\hline \multirow[t]{37}{*}{ District } & 5 and 10 & 26 & 0.176 & -0.111 & -0.166 & -0.171 \\
\hline & & & 0.391 & 0.589 & 0.418 & 0.404 \\
\hline & Camino verde & 29 & -0.151 & 0.111 & 0.067 & 0.03 \\
\hline & & & 0.434 & 0.565 & 0.729 & 0.876 \\
\hline & Centro & 19 & -0.232 & -0.097 & -0.161 & -0.287 \\
\hline & & & 0.339 & 0.694 & 0.511 & 0.233 \\
\hline & Cerro colorado & 44 & 0.321 & -0.077 & -0.208 & -0.03 \\
\hline & & & 0.033 & 0.621 & 0.176 & 0.844 \\
\hline & Chapultepec & 19 & -0.485 & 0.025 & 0.161 & 0.200 \\
\hline & & & 0.035 & 0.92 & 0.51 & 0.411 \\
\hline & Ciudad & 22 & 0.056 & -0.09 & -0.255 & $0.48 *$ \\
\hline & industrial & & 0.804 & 0.691 & 0.253 & 0.024 \\
\hline & El monumento $\#$ & & & & & \\
\hline & La gloria & 9 & -0.059 & -0.307 & 0.535 & -0.32 \\
\hline & & & 0.881 & 0.422 & 0.138 & 0.401 \\
\hline & Los pinos & 24 & -0.198 & 0.143 & 0.263 & 0.32 \\
\hline & & & 0.355 & 0.504 & 0.215 & 0.127 \\
\hline & Matamoros & 26 & 0.059 & 0.026 & 0.17 & 0.361 \\
\hline & & & 0.774 & 0.899 & 0.407 & 0.07 \\
\hline & Mesa de otay & 29 & -0.057 & 0.026 & -0.104 & -0.005 \\
\hline & & & 0.771 & 0.895 & 0.593 & 0.979 \\
\hline & Nido de las aguilas & 17 & -0.315 & -0.114 & 0.258 & -0.102 \\
\hline & & & 0.217 & 0.662 & 0.318 & 0.697 \\
\hline & Ojo de agua & 5 & 0.752 & 0.862 & $\dagger$ & 0.18 \\
\hline & & & 0.143 & 0.6 & $\dagger$ & 0.773 \\
\hline & Parque industrial flo & rido $^{\#}$ & & & & \\
\hline & Playas de tijuana & 30 & -0.118 & 0.304 & 0.324 & -0.052 \\
\hline & & & 0.534 & 0.103 & 0.081 & 0.785 \\
\hline & San Antonio de los & 40 & 0.112 & -0.101 & 0.062 & 0.011 \\
\hline & buenos & & 0.491 & 0.534 & 0.703 & 0.945 \\
\hline & San Luis & 12 & 0.383 & $0.764 * *$ & $0.745^{* *}$ & 0.313 \\
\hline & & & 0.219 & 0.004 & 0.005 & 0.321 \\
\hline & Santa $\mathrm{fe}^{\#}$ & & & & & \\
\hline & Terrazas del valle & 14 & -0.169 & -0.197 & 0.414 & 0.139 \\
\hline & & & 0.563 & 0.5 & 0.414 & 0.636 \\
\hline & Villafontana & 24 & -0.177 & 0.247 & 0.241 & 0.346 \\
\hline & & & 0.407 & 0.245 & 0.257 & 0.097 \\
\hline
\end{tabular}

\#Districts with not stable data.

$\dagger$ No other uses than residential.

* Significant correlation at 0.05 level (2-tailed).

**Significant correlation at 0.01 level (2-tailed).

$0.217=$ Significant value . 

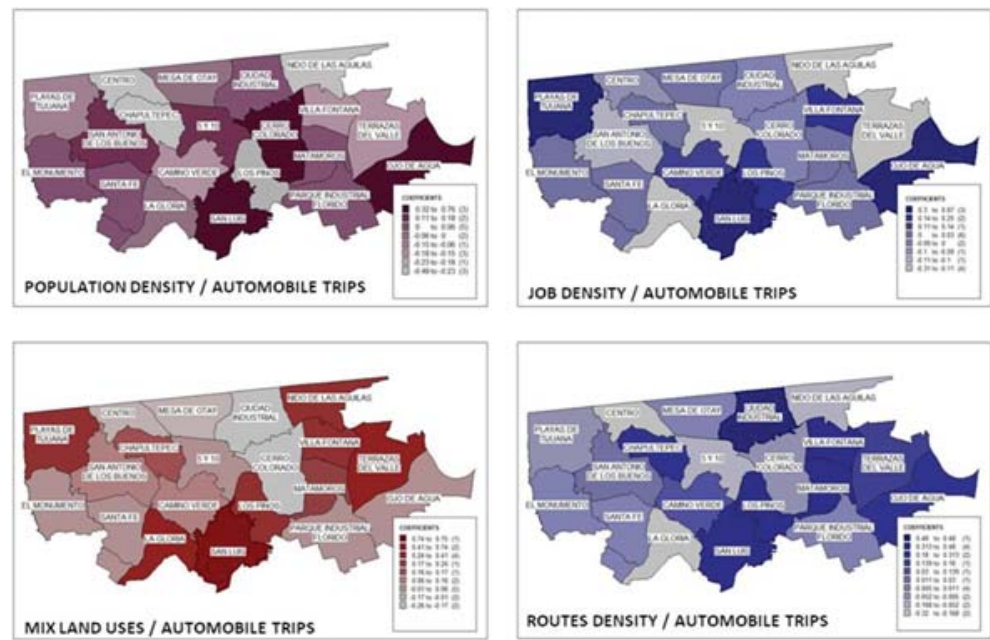

Figure 6: Pearson correlation coefficients by urban district in Tijuana.

Table 7: Urban form correlations for districts ' 5 and 10' and 'Centro'.

\begin{tabular}{|c|c|c|c|c|c|c|c|c|}
\hline \multirow{3}{*}{\multicolumn{2}{|c|}{ City/district }} & \multirow[b]{3}{*}{$\mathrm{N}$} & \multicolumn{6}{|c|}{ Urban form correlation } \\
\hline & & & \multicolumn{3}{|c|}{ Population density } & \multicolumn{2}{|c|}{ Jobs density } & $\begin{array}{c}\text { Non-residential } \\
\text { uses }\end{array}$ \\
\hline & & & $\begin{array}{c}\text { Jobs } \\
\text { density }\end{array}$ & $\begin{array}{l}\text { Non- } \\
\text { residential } \\
\text { uses }\end{array}$ & $\begin{array}{l}\text { Transit } \\
\text { routes } \\
\text { density }\end{array}$ & $\begin{array}{l}\text { Non- } \\
\text { residential } \\
\text { uses }\end{array}$ & $\begin{array}{l}\text { Transit } \\
\text { routes }\end{array}$ & $\begin{array}{c}\text { Transit routes } \\
\text { density }\end{array}$ \\
\hline \multirow{2}{*}{\multicolumn{2}{|c|}{ City }} & 396 & $-0.112 *$ & $-0.249 * *$ & $0.203 * *$ & $0.562 * *$ & $0.449 * *$ & $0.242 * *$ \\
\hline & & & 0.026 & 0 & 0 & 0 & 0 & 0 \\
\hline \multirow[t]{4}{*}{ District } & 5 and 10 & 26 & -0.045 & -0.279 & -0.239 & $0.664 * *$ & $0.436^{*}$ & 0.371 \\
\hline & & & 0.827 & 0.167 & 0.24 & 0 & 0.026 & 0.062 \\
\hline & Centro & 19 & $-0.487 *$ & $-0.669 * *$ & -0.377 & $0.866^{* *}$ & $0.819 * *$ & $0.71 * *$ \\
\hline & & & 0.034 & 0.002 & 0.112 & 0 & 0 & 0.001 \\
\hline
\end{tabular}

*Significant correlation at 0.05 level (2-tailed).

**Significant correlation at 0.01 level (2-tailed).

$0.217=$ Significant value . 
Table 8: Urban form and other transportation modes correlations for districts ' 5 and 10' and 'Centro'.

\begin{tabular}{|c|c|c|c|c|c|c|c|c|c|c|}
\hline \multirow{3}{*}{\multicolumn{2}{|c|}{ City/district }} & \multirow[b]{3}{*}{$\mathrm{N}$} & \multicolumn{8}{|c|}{ Urban form/other transportation modes correlations } \\
\hline & & & \multicolumn{2}{|c|}{$\begin{array}{l}\text { Population } \\
\text { density }\end{array}$} & \multicolumn{2}{|c|}{$\begin{array}{c}\text { Job } \\
\text { density }\end{array}$} & \multicolumn{2}{|c|}{$\begin{array}{l}\text { Non-residential } \\
\text { uses }\end{array}$} & \multicolumn{2}{|c|}{$\begin{array}{l}\text { Transit } \\
\text { routes density }\end{array}$} \\
\hline & & & $\begin{array}{c}\text { Walking } \\
\text { trips }\end{array}$ & $\begin{array}{l}\text { Transit } \\
\text { trips }\end{array}$ & $\begin{array}{l}\text { Walking } \\
\text { trips }\end{array}$ & $\begin{array}{c}\text { Transit } \\
\text { trips }\end{array}$ & $\begin{array}{c}\text { Walking } \\
\text { trips }\end{array}$ & $\begin{array}{c}\text { Transit } \\
\text { trips }\end{array}$ & $\begin{array}{l}\text { Walking } \\
\text { trips }\end{array}$ & $\begin{array}{c}\text { Transit } \\
\text { trips }\end{array}$ \\
\hline \multirow{2}{*}{\multicolumn{2}{|c|}{ City }} & 396 & 0.052 & 0.086 & $-0.124 *$ & -0.048 & $-0.18^{* *}$ & -0.069 & -0.084 & 0.078 \\
\hline & & & 0.307 & 0.25 & 0.013 & 0.344 & 0 & 0.168 & 0.097 & 0.121 \\
\hline \multirow[t]{4}{*}{ District } & 5 and & 26 & 0.079 & $-0.463^{*}$ & 0.002 & $0.47 *$ & -0.035 & $0.567 * *$ & -0.04 & $0.486 *$ \\
\hline & 10 & & 0.701 & 0.017 & 0.993 & 0.015 & 0.864 & 0.003 & 0.846 & 0.012 \\
\hline & Centro & 19 & $0.481 *$ & -0.448 & -0.207 & 0.439 & -0.188 & $0.538 *$ & 0.014 & $0.488 *$ \\
\hline & & & 0.037 & 0.052 & 0.395 & 0.06 & 0.441 & 0.018 & 0.954 & 0.034 \\
\hline
\end{tabular}

* Significant correlation at 0.05 level (2-tailed).

**Significant correlation at 0.01 level (2-tailed).

$0.217=$ Significant value
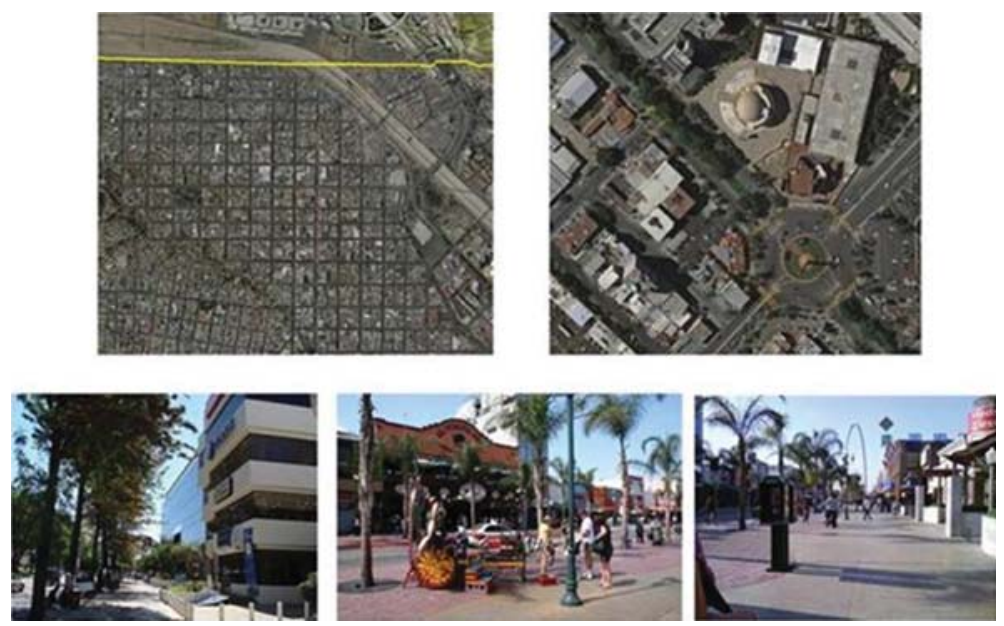

Figure 7: Urban conditions in core districts of Tijuana. 


\section{CONCLUSIONS}

The evaluation of accessibility to different scales at the Tijuana-Rosarito-Tecate metropolitan region will allow identifying relevant urban form factors that determine automobile travel behavior.

The results at urban scale identify several contradictorial conclusions. First, at the city level the urban structure does not respond to the traditional pattern of developed cities. Here, the land use-transportation interaction shows that land use distribution is segregated, that residential zones act as dormitories. Then, commercial, services and industries generates more auto trips, even if there is a concentration of transit routes. Finally, distance from center implies fewer auto trips, possibly because of social conditions (in Tijuana, most of the peripheral development is related with illicit and poor settlements).

At the district level, there were no significant correlation between urban form factors and auto trips. Nevertheless, in contrast with the results at the city level, negative correlations appear in several districts, highlighting 'El Centro' and ' 5 and 10 ' as the districts with more negative coefficients. This conducts a specific analysis of urban form factors and other transportation modes in these two districts. The results told that there is a significant relation between mixed uses, transit routes density and transit transportation, and that population density is one urban factor that increases walking trips in 'El Centro'. Distribution of land uses, transit routes density and population and jobs density in these districts could be observed as conditions to improve accessibility in the rest of the city; but most important, Tijuana and its metropolitan space have to be structured in a way that these indicators could serve as a guide to relate land use and transportation systems. The second phase of this work will include the analysis at the metropolitan scale in which will be correlated land use and transportation factors around subcenters.

Urban strategies at city and district levels to link land use and transportation systems must recognized the need of an efficient urban structure. Planning officials should work towards the construction of a set of indicators to evaluate the progress of a new urban and transportation structure for the city. Urban form management to reorganized land uses towards reducing automobile trips will include the following:

- Complement residential districts with commercial services and public facilities.

- Promote and facilitate productive activities (jobs) inside residential districts, considering compatibility.

- Complement public services and urbanization; street opening, walking and cyclist paths.

- Complement and create local centers with good communication, by public transportation, walking and cycling.

- Better urban design and streetscape.

These strategies must be included in the General Plan and implemented by zoning regulation. Public officials of land use and transportation departments should be coordinated by more integrated strategies; actions over the land use system have to be monitored by transportation indicators and vice versa. This could only be achieved by a unified vision of the importance of land use-transportation interaction within the municipal government. Also, there must be coordination among other scales of government because urban transportation in Tijuana is a multi jurisdictional issue. Metropolitan and cross border issues arise, so local authorities have to be prepared with a common strategy.

The complexity of the sustainable urban development concept makes difficult to move from theory to practice. Contrasting the traditional exercise of urban planning, the new focus of sustainability adds difficulty in the development of instruments to design more responsible cities. To this effect, 
the recognition of urban dynamics as a result of metabolic processes allows developing comprehensive solutions to urban and regional sustainability issues. In the search of integrated responses, the application of flexible concepts like accessibility will permit linking the land use-transportation planning processes to develop more sustainable models of urban management.

The environmental challenges shared in a metropolitan region so dynamic like Tijuana-RosaritoTecate and its North American counterpart of San Diego, demand the definition of growth management processes based in common principles. Considering that the basic premise of sustainable transportation is the reduction of motor vehicle trips, it is imperative the definition of common policies so it can permit reinforce a joint land use-transportation planning processes to achieve best accessibility conditions from the basic urban unit to the regional cross border scale.

\section{REFERENCES}

[1] Silva, C. \& Pinho, P., A Methodology to Assess the Contribution of the Land Use and Transport Systems to Sustainable Urban Mobility, CITTA - Research Centre of Territory, Transport and Environment, University of Oporto: Portugal, 2006, http://www.etcproceedings.org/paper/ a-methodology-to-assess-the-contribution-of-the-land-use-and-transport-systems.

[2] Newman, P. \& Kenworthy, J., Sustainability and Cities: Overcoming Automobile Dependence, Island Press: Washington, DC, 1999.

[3] Cervero, R. \& Kockeman, K., Travel demand and the 3Ds: density, diversity and design: transportation research part D. Transport and Environment, 2(3), pp. 199-219, 1997. doi:http://dx.doi.org/10.1016/S1361-9209(97)00009-6

[4] Litman, T., Land Use Impacts on Transport: How Land Use Factors Affect Travel Behavior. Victory Transport Policy Institute, 2008, http://www.vtpi.org/landtravel.pdf

[5] Lautso, K., Spiekermann, K., Wegener, M., Sheppard, I., Steadman, P., Martinus, A., Domingo, R. \& Gayda, S., PROPOLIS: Planning and Research of Policies for Land Use and Transport for Increasing Urban Sustainability, 2nd edn, European Commission, Thematic Energy Program, Environmental and Sustainable Development: Helsinky, 2004.

[6] Litman, T., Sustainable transportation indicators: a recommended program to define a standard set of indicators for sustainable transportation planning. Transportation Research Board, 2008, http://www.vtpi.org/sustain/sti.pdf

[7] Wegener, M. \& Fürst, F., Land-Use Transport Interaction: State of the Art. IRPUD, Dortmund University: Dortmund, Germany, 1999, http://129.3.20.41/eps/urb/papers/0409/0409005.pdf

[8] Stead, D. \& Marshall, S., The relationships between urban form and travel patterns. An international review and evaluation. European Journal of Transport and Infrastructure Research, 1(2), pp. 113-141, 2001.

[9] Liu, S. \& Zhu, X., Accessibility analyst: an integrated GIS tool for accessibility analysis in urban transportation planning. Environment and Planning B: Planning and Design 2004, 31(1), pp. 105-124, 2003. doi:http://dx.doi.org/10.1068/b305

[10] De Sousa, D., Sustainable Urban form, Accessibility and Travel: the Relationship between Polycentric Urban Development and Commuting in Lisbon. Architectural School, Planning and Landscape, University of Newcastle: Newcastle, 2008, https://theses.ncl.ac.uk/dspace/ bitstream/10443/122/1/vale09.pdf

[11] Newman, P. \& Kenworthy, J., Urban design to reduce automobile dependence. Opolis: An International Journal of Suburban and Metropolitan Studies, 2(1), pp. 35-52, 2006.

[12] Milakis, D., Vlastos, T. \& Barbopoulos, N., Relationships between urban form and travel behavior in Athens, Greece: a comparison with western European and North American results. European Journal of Transport and Infrastructure Research, 8(3), pp. 201-215, 2007. 
[13] Van Acker, V. \& Witlox, F., Exploring the Relationships between Land-use System and Travel Behavior: Some First Findings. European Regional Science Association, Vrije University: Amsterdam, 2005, http://www-sre.wu-wien.ac.at/ersa/ersaconfs/ersa05/papers/601.pdf

[14] Bertaud, A., The spatial organization of cities: deliberate outcome or unforeseen consequence? World Development Report 2003, Dynamic Development in a Sustainable World, Background Paper, http://www.econ.worldbank.org/files/15934_Bertraud.pdf

[15] Lawrence, D.F. \& Pivo, G., Impacts of mixed use and density on utilization of three modes of travel: single-occupant vehicle, transit, and walking. Transportation Research Record, 1466, pp. 44-52, 1994.

[16] Consejo Nacional de Población (Conapo)-Secretaría de Desarrollo Social (Sedesol)-Instituto Nacional de Estadística, Geografía e Informática (NEGI), Delimitación de las zonas metropolitanas de México, 2007, http://www.conapo.gob.mx/index.php?option=com_co ntent $\&$ view $=$ article $\&$ id $=133 \&$ Itemid $=212$

[17] Instituto Municipal de Planeación (Implan), Programa de desarrollo urbano de centro de población de la ciudad de Tijuana. XIX Ayuntamiento de Tijuana: Tijuana, BC, 2009.

[18] San Diego Association of Governments (Sandag), Fast Facts. San Diego Association of Governments: San Diego, CA, 2007, http://www.sandag.org/resources/demographics_and_other_data/demographics/fastfacts/regi.htm

[19] Gangster, P. ed., Border Environmental: A Road to a Sustainable 2020, SCERP Monograph Series, no. 1, St. James State University Press: St. Diego, 2000.

[20] Secretaría de Medio Ambiente y Recursos Naturales-Gobierno del Estado de Baja California, Programa para mejorar la calidad del aire en Tijuana-Rosarito, México: Secretaría del Medio ambiente y Recursos Naturales, 2000, http://www2.ine.gob.mx/publicaciones/consultaPublicacion.html?id_pub=328

[21] Instituto Municipal de Planeación (Implan), Plan maestro de vialidad y transporte para la ciudad de Tijuana, BC, Tijuana, BC, 2006.

[22] Instituto Nacional de Estadística Geografía e Informática (INEGI), II Conteo de Población y Vivienda, 2005, http://www.inegi.gob.mx/est/default.aspx?c=6848\&pred=1

[23] Instituto Nacional de Estadística Geografía e Informática (INEGI), Censo económico, 2004. 